\title{
Actinomyces suimastitidis sp. nov., isolated from pig mastitis
}

\footnotetext{
1 Department of Food Science and Technology, University of Reading, Whiteknights, Reading RG6 6AP, UK

2 Culture Collection, Department of Clinical Bacteriology, University of Göteborg, S-413 46 Göteborg, Sweden

3 National Veterinary Institute, S-75007 Uppsala, Sweden

${ }^{4}$ Centre for Reproductive Biology in Uppsala, Department of Obstetrics and Gynaecology, Swedish University of Agricultural Sciences, SE-75007 Uppsala, Sweden
}

\author{
Lesley Hoyles, ${ }^{1}$ Enevold Falsen, ${ }^{2}$ Gull Holmström, ${ }^{3}$ Arne Persson, ${ }^{4}$ \\ Berit Sjödén ${ }^{2}$ and Matthew D. Collins ${ }^{1}$
}

Author for correspondence: Matthew D. Collins. Tel: +44 118935 7226. Fax: +44 1189357222. e-mail: m.d.collins@reading.ac.uk

\begin{abstract}
An unusual Actinomyces-like bacterium originating from a pig with mastitis was subjected to a polyphasic taxonomic investigation. The morphological and biochemical characteristics of the organism were consistent with its preliminary assignment to the genus Actinomyces but it did not appear to correspond to any recognized species. PAGE analysis of whole-cell proteins confirmed the phenotypic distinctiveness of the bacterium and 16S rRNA gene sequence analysis demonstrated that it represents a hitherto unknown sub-line amongst a cluster of Actinomyces species which embraces Actinomyces canis, Actinomyces georgiae, Actinomyces hyovaginalis, Actinomyces meyeri, Actinomyces odontolyticus, Actinomyces radingae and Actinomyces turicensis. Based on phylogenetic and phenotypic evidence, it is proposed that the unknown bacterium isolated from pig mastitis be classified as Actinomyces suimastitidis sp. nov. The type strain of Actinomyces suimastitidis is CCUG 39276 $^{\top}$ ( = CIP 106779').
\end{abstract}

Keywords: taxonomy, phylogeny, Actinomyces suimastitidis, 16S rRNA, pig mastitis

\section{INTRODUCTION}

The genus Actinomyces is one of the largest genera within the high $\mathrm{G}+\mathrm{C}$ Gram-positive bacteria embracing a heterogeneous collection of anaerobic and facultatively anaerobic, asporogenous, non-acid-fast, filamentous or diphtheroidal rod-shaped organisms (Schaal, 1986). Many Actinomyces species are known to be indigenous to mucous membranes of humans and animals, and several species are established pathogens. The reliable identification of Actinomyces species by conventional phenotypic methods has in the past often been difficult. Although the use of commercial miniaturized biochemical kits has led to improvements in the identification of many species, many novel or unusual strains continue to pose problems. Over the past few years the application of molecular chemical and molecular genetic methods of analysis has greatly clarified the taxonomy of this important group of organisms. Furthermore, these molecular-based techniques have proved to be excellent tools for the detection/recognition of novel

The GenBank accession number for the $16 \mathrm{~S}$ rRNA gene of CCUG $39276^{\top}$ is AJ277385. species as well as those listed in commercial databases, including aberrant types. Indeed, primarily due to the use of molecular-based technologies, the number of validated Actinomyces has increased dramatically [e.g. Actinomyces bowdenii (Pascual et al., 1999), Actinomyces europaeus (Funke et al., 1997), Actinomyces graevenitzii (Pascual et al., 1997b), Actinomyces neuii subsp. anitratus and Actinomyces neuii subsp. neuii (Funke et al., 1994), Actinomyces radingae (Wüst et al., 1995) and Actinomyces turicensis (Wüst et al., 1995)]. In this article, we have characterized an unusual Actinomyces-like organism from a pig with mastitis using phenotypic and molecular phylogenetic methods. Based on the presented findings, yet another new species of the genus Actinomyces, Actinomyces suimastitidis, is described.

\section{METHODS}

Culture and biochemical characterization. Strain CCUG $39276^{\mathrm{T}}$ was isolated from a specimen collected from a mammary gland of a sow with a chronic granulomatous mastitis. The isolate was cultured on Columbia agar (Difco) supplemented with $5 \%$ horse blood at $37^{\circ} \mathrm{C}$, in air plus $5 \%$ $\mathrm{CO}_{2}$, and biochemically characterized by using the API rapid ID32Strep and API CORYNE systems according to the manufacturer's instructions (API bioMérieux). 


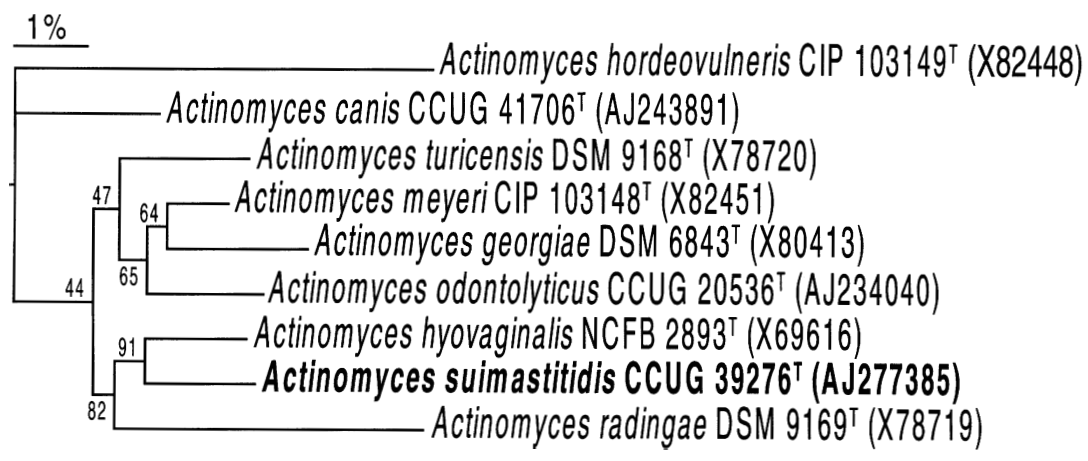

\begin{abstract}
Fig. 1. Unrooted tree showing the phylogenetic relationships of Actinomyces suimastitidis sp. nov. and its closest relatives. The tree, constructed using the neighbourjoining method, was based on a comparison of approximately 1327 nucleotides. Bootstrap values, expressed as a percentage of 500 replications, are given at branching points. Scale bar, $1 \%$ sequence divergence.
\end{abstract}

\begin{abstract}
Whole-cell protein profiling. PAGE analysis of whole-cell proteins was performed as described by Pot et al. (1994). For densitometric analysis, normalization and interpretation of protein patterns, the GelCompar 3.0 software package (Applied Maths, Kortrijk, Belgium) was used. The similarity between all pairs of traces was expressed by the Pearson product moment correlation coefficient converted for convenience to a percentage similarity.
\end{abstract}

16S rRNA gene sequencing and phylogenetic analyses. The $16 \mathrm{~S}$ rRNA gene of the isolate was amplified by PCR and directly sequenced using a Taq Dye-Deoxy Terminator Cycle Sequencing kit (Applied Biosystems) and an automatic DNA sequencer (model 373A; Applied Biosystems). The closest known relatives of the new isolate were determined by performing database searches. These sequences and those of other known related strains were retrieved from the GenBank or Ribosomal Database Project Libraries and aligned with the newly determined sequence using the program PILEUP (Devereux et al., 1984). The resulting multiple sequence alignment was corrected manually and a distance matrix was calculated using the programs PRETTY and DNADIST (using the Kimura-2 correction parameter) (Felsenstein, 1989). A phylogenetic tree was constructed according to the neighbour-joining method with the program NEIGHBOR (Felsenstein, 1989). The stability of the groupings was estimated by bootstrap analysis (500 replications) using the programs DNABOOT, DNADIST, NEIGHBOR and CONSENSE. The 16S rRNA gene sequence of strain CCUG $39276^{\mathrm{T}}$ has been deposited in GenBank under accession number AJ277385.

\section{RESULTS AND DISCUSSION}

The isolate consisted of Gram-positive straight to slightly curved rods which were non-acid-fast and nonspore-forming. The strain was catalase-negative and facultatively anaerobic. Using API systems acid was produced from glucose, L-arabinose (weak), melibiose, pullulan, D-raffinose, ribose (weak), sucrose and Dxylose. Different results were obtained for acid production from maltose. Using the API CORYNE system acid was produced from this substrate but with the API rapid ID32Strep system acid production was not detected. Activities for alanine phenylalanine proline arylamidase, $\alpha$-glucosidase, $\beta$-glucosidase, $\alpha$ galactosidase, $\beta$-galactosidase, and pyrazinamidase (weak) were detected. The cellular morphology and biochemical reactions of the isolate were consistent with its preliminary assignment to the genus Actinomyces. To assess the phenotypic resemblance of the isolate to reference Actinomyces species, a comparative analysis of whole-cell protein profiles by SDS-PAGE was performed. The isolate was found to be different from all Actinomyces species described to date and did not show a close resemblance to any particular species. The nearest relatives to the unidentified bacterium on the basis of protein profiling corresponded to Actinomyces odontolyticus, Actinomyces georgiae and Actinomyces meyeri. However, the correlation values were less than $65 \%$ (data not shown). To determine the phylogenetic affinities of the clinical isolate, its almost complete 16S rRNA gene (1416 nucleotides) was sequenced and subjected to a comparative analysis. Sequence database searches confirmed that the unknown bacterium was most closely related to species of the genus Actinomyces (results not shown). Highest sequence relatedness was shown with Actinomyces hyovaginalis (96.4\% sequence similarity), Actinomyces meyeri (95.4\%), Actinomyces turicensis $(95.5 \%)$ and Actinomyces odontolyticus $(95.1 \%)$. The results of neighbour-joining analysis are shown in Fig. 1 and confirmed the association of the Actinomyces-like isolate with Actinomyces hyovaginalis and related species, with the clinical isolate forming a distinct sub-line. Pairwise homology values over the whole of the genus Actinomyces ranged from 89.4 to $93.9 \%$, with the unidentified pig isolate exhibiting $90.7 \%$ sequence similarity with Actinomyces bovis, the type species of the genus.

The genus Actinomyces embraces a phenotypically very diverse range of organisms and currently over 20 different species are assigned to the genus. It is, however, recognized that the genus is not monophyletic and actually consists of several distinct rRNA lineages (e.g. Pascual et al., 1997a, 1999; Lawson et al., 1997). It is evident from the present 16S rRNA study that the novel bacterium from a pig forms a distinct sub-line within a phylogenetically robust cluster of species which includes Actinomyces canis, Actinomyces georgiae, Actinomyces hyovaginalis, Actinomyces meyeri, Actinomyces odontolyticus, Actinomyces radingae and Actinomyces turicensis. Sequence divergence values of $3 \cdot 6-6 \cdot 1 \%$ with other members of this rRNA Actinomyces cluster clearly indicate that the pig 
Table 1. Tests which are useful in distinguishing Actinomyces suimastitidis sp. nov. from some other animal Actinomyces species and related taxa

+ , Positive; - , negative; v, variable; $+(-)$, a few strains negative.

\begin{tabular}{|c|c|c|c|c|c|c|c|c|c|c|c|c|c|c|c|}
\hline \multirow[t]{2}{*}{ Species } & \multicolumn{7}{|c|}{ Acid from:* } & \multicolumn{6}{|c|}{ Production of $: \dagger$} & \multirow{2}{*}{$\begin{array}{c}\text { Reduction of } \\
\mathrm{NO}_{3}\end{array}$} & \multirow{2}{*}{$\begin{array}{l}\text { Hydrolysis of } \\
\text { aesculin }\end{array}$} \\
\hline & L-Ara & Mlz & D-Rib & Suc & Tre & D-Xyl & Pull & $\alpha$-Gal & $\alpha$-Glu & $\beta$-Glu & Pyr & GTA & APPA & & \\
\hline Actinomyces suimastitidis sp. nov. & + & - & + & + & - & + & + & + & + & + & + & - & + & - & + \\
\hline Actinomyces bovis & - & - & - & $+(-)$ & - & - & - & - & - & $\mathrm{V}$ & - & $\mathrm{V}$ & - & - & $+(-)$ \\
\hline Actinomyces bowdenii & - & + & $\mathrm{V}$ & + & + & - & - & + & $\mathrm{V}$ & + & $\mathrm{V}$ & - & + & + & + \\
\hline Actinomyces canis & + & - & + & $\mathrm{V}$ & - & + & + & + & + & - & + & $\mathrm{V}$ & + & - & - \\
\hline Actinomyces denticolens & - & $\mathrm{V}$ & $\mathrm{V}$ & + & $\mathrm{V}$ & $\mathrm{V}$ & $\mathrm{V}$ & + & + & + & $\mathrm{v}$ & - & $\mathrm{V}$ & + & + \\
\hline Actinomyces hordeovulneris & - & - & $\mathrm{V}$ & $\mathrm{V}$ & $\mathrm{V}$ & + & + & + & $\mathrm{v}$ & + & $\mathrm{V}$ & + & + & - & + \\
\hline Actinomyces howellii & - & $\mathrm{V}$ & - & + & $\mathrm{V}$ & + & - & + & + & + & + & - & + & - & + \\
\hline Actinomyces hyovaginalis & $+(-)$ & - & + & + & - & + & - & + & + & + & $\mathrm{v}$ & - & + & $\mathrm{v}$ & + \\
\hline Actinomyces slackii & - & - & - & + & + & + & - & + & + & + & + & - & - & + & + \\
\hline Actinobaculum suis & - & - & $\mathrm{V}$ & - & - & + & - & - & + & $\mathrm{v}$ & - & - & + & - & $\mathrm{V}$ \\
\hline
\end{tabular}

* Fermentation of: L-Ara, L-arabinose; Mlz, melezitose; D-Rib, D-ribose; Suc, sucrose; Tre, trehalose; D-Xyl, D-xylose; Pull, pullulan.

$\dagger$ Production of: $\alpha$-Gal, $\alpha$-galactosidase; $\alpha$-Glu, $\alpha$-glucosidase; $\beta$-Glu, $\beta$-glucosidase; Pyr, pyrazinamidase; GTA, glycyl tryptophan arylamidase; APPA, alanyl-phenylalanine proline arylamidase. 
isolate represents a new species. Although there is no precise correlation between percentage 16S rRNA divergence values and species delineation, it is generally recognized that organisms displaying values close to $3 \%$ or more do not belong to the same species (Stackebrandt \& Goebel, 1994). The observed > 3\% sequence divergence between the unknown rod-shaped clinical isolate and currently described Actinomyces species is therefore consistent with separate species status. Support for the distinctiveness of the unknown pig bacterium also comes from phenotypic evidence. The unknown bacterium can be biochemically readily distinguished from all other described Actinomyces species (Table 1). Furthermore, the bacterium formed a distinct and isolated line on PAGE analysis of wholecell proteins (data not shown). Therefore, based on the distinct phenotypic characteristics of the unknown rod-shaped bacterium and molecular chemical and molecular genetic evidence, we believe the clinical isolate warrants classification as a new species of the genus Actinomyces, for which the name Actinomyces suimastitidis is proposed. Biochemical tests which are useful in distinguishing Actinomyces suimastitidis from other animal Actinomyces species are shown in Table 1.

\section{Description of Actinomyces suimastitidis sp. nov.}

Actinomyces suimastitidis (su.i.mas.ti'ti.dis. N.L. sus pig; M.L. n. mastitis infection of the milk glands, N.L. gen. n. suimastitidis of porcine mastitis).

Cells are straight to slightly curved rods which stain Gram-positive, are non-acid-fast and non-motile. Facultatively anaerobic and catalase-negative. Using API systems acid is produced from D-glucose, Larabinose (weak), melibiose, pullulan, D-raffinose, ribose (weak), sucrose and D-xylose. Acid is not produced from D-arabitol, cyclodextrin, lactose, mannitol, melezitose, methyl $\beta$-D-glucopyranoside, sorbitol, trehalose or tagatose. Acid may or may not be produced from maltose. Aesculin is hydrolysed but gelatin and hippurate are not hydrolysed. Alanine phenylalanine proline arylamidase, $\alpha$-galactosidase, $\beta$ galactosidase, $\alpha$-glucosidase, $\beta$-glucosidase and pyrazinamidase (weak) are produced. Arginine dihydrolase, $\beta$-glucuronidase, glycyl tryptophan arylamidase, $\beta$-mannosidase, pyroglutamic acid arylamidase and urease are not produced. Alkaline phosphatase and $N$ acetyl- $\beta$-glucosaminidase may or may not be produced. Acetoin production is weakly positive. Nitrate is not reduced to nitrite. Isolated from pig mastitis. Pathological significance is not known. Habitat is not known. The type strain is CCUG $39276^{\mathrm{T}}$ (= CIP $\left.106779^{\mathrm{T}}\right)$.

\section{ACKNOWLEDGEMENTS}

We are grateful to Hans Trüper for help in coining the species name. The support of Lena Eliasson-Selling and Maria Lindberg is acknowledged.

\section{REFERENCES}

Devereux, J., Haeberli, P. \& Smithies, O. (1984). A comprehensive set of sequence analysis programs for the VAX. Nucleic Acids Res 12, 387-395.

Felsenstein, J. (1989). PHYLIP - phylogeny inference package (version 3.2). Cladistics 5, 164-166.

Funke, G., Stubbs, S., von Graevenitz, A. \& Collins, M. D. (1994). Assignment of human-derived CDC group 1 coryneform bacteria and CDC group 1-like coryneform bacteria to the genus Actinomyces as Actinomyces neuii subsp. neuii sp. nov., subsp. nov., and Actinomyces neuii subsp. anitratus subsp. nov. Int J Syst Bacteriol 44, 167-171.

Funke, G., Alvarez, N., Pascual, C., Falsen, E., Akervall, E., Sabbe, L., Schouls, L., Weiss, N. \& Collins, M. D. (1997). Actinomyces europaeus sp. nov., isolated from human clinical specimens. Int J Syst Bacteriol 47, 687-692.

Lawson, P. A., Falsen, E., Akervall, E., Vandamme, P. \& Collins, M. D. (1997). Characterization of some Actinomyces-like isolates from human clinical specimens: reclassification of Actinomyces suis (Soltys and Spratling) as Actinobaculum suis comb. nov. and description of Actinobaculum schaalii sp. nov. Int $J$ Syst Bacteriol 47, 899-903.

Pascual, C., Foster, G. \& Collins, M. D. (1997a). Phylogenetic analysis of the genus Actinomyces based on 16S rRNA gene sequences: description of Arcanobacterium phocae sp. nov., Arcanobacterium bernardiae comb. nov., and Arcanobacterium pyogenes comb. nov. Int $J$ Syst Bacteriol 47, 46-53.

Pascual, C., Falsen, E., Akervall, E., Sjoden, B. \& Collins, M. D. (1997b). Actinomyces graevenitzii sp. nov., isolated from human clinical specimens. Int J Syst Bacteriol 47, 885-888.

Pascual, C., Foster, G., Falsen, E., Bergström, K., Greko, C. \& Collins, M. D. (1999). Actinomyces bowdenii sp. nov., isolated from canine and feline clinical specimens. Int $J$ Syst Bacteriol 49, 1873-1877.

Pot, B., Vandamme, P. \& Kersters, K. (1994). Analysis of electrophoretic whole-organism protein fingerprints. In Modern Microbial Methods. Chemical Methods in Prokaryotic Systematics, pp. 493-521. Edited by M. Goodfellow \& A. G. O’Donnell. Chichester: Wiley.

Schaal, K. P. (1986). Genus Actinomyces. In Bergey's Manual of Systematic Bacteriology, vol. 2, pp. 1383-1418. Edited by P. H. A. Sneath, N. S. Mair, M. E. Sharpe \& J. G. Holt. Baltimore: Williams \& Wilkins.

Stackebrandt, E. \& Goebel, B. M. (1994). Taxonomic note: a place for DNA-DNA reassociation and 16S rRNA sequence analysis in the present species definition in bacteriology. Int $J$ Syst Bacteriol 44, 846-849.

Wüst, J., Stubbs, S., Weiss, N., Funke, G. \& Collins, M. D. (1995). Assignment of Actinomyces pyogenes-like (CDC coryneform group E) bacteria to the genus Actinomyces as Actinomyces radingae sp. nov. and Actinomyces turicensis sp. nov. Lett Appl Microbiol 20, 76-81. 